cobalt-60 sources. The effects of the inhomogeneity of body tissues on the dose received in the various tumour sites, and also the relative biological effect of the various qualities of radiations used in radiotherapeutic practice are being investigated.

Methods of calorimetric dosimetry are being perfected to enable an accurate measure of beams of high intensity but short duration, such as are met with when using the linear accelerator. Scintillation dosimetric techniques can now be applied with an energy response constant to \pm 10 per cent over the range $20 \mathrm{keV}$. to $2 \mathrm{MeV}$.

At the other end of the activity scale, equipment has been constructed for the continuous monitoring of the natural radioactivity of the atmosphere, and regular measurements are being made of the radon content of the air in both hemispheres. Measurements have also been made of the natural radioactivity of different types of building materials from different parts of the world, and calculations carried out on the doses received at the gonads for both males and females. With the increasing development of radioactive materials, arising from a variety of uses from the luminescence of wrist-watches to the 'fall out' resulting from atomic explosions, the radiation dosage-level of the population as a whole becomes of increasing importance. This is confirmed in this report by the increasing use of radioactive isotopes, not as therapeutic agents, but as diagnostic and research tools, for labelling red blood cells with iron-59, for radiography with thulium-170 and xenon-133, and for diagnostic tests for thyrotoxicosis using iodine-131, to mention but a few of the numerous routine uses.

\title{
SCIENCE BY THE UPPER FORM
}

A SLSSION of Section X (Assembly of Corresponding Societies) of the British Association meeting at Sheffield was devoted to a series of papers by sixth-form pupils under the title "Science by the Upper Form". Its object was two-fold : to introduce the young people to the meetings of the Association and to give adult listeners an insight into the work and interests of potential scientists.

The session was popular and attracted the largest audience that the Section enjoyed. The papers covered a wide range, from a consideration of the teaching of the history of science in schools to the mating customs of bullfinches, and from a school astronomical project to observations upon animal life in a stream. They were all indicative of much careful thought, and, where the subject demanded it, close and continuous observation combined with accuracy in recording. The young people were to be congratulated on their timing. None exceeded the limit imposed and some ended with a few minutes in hand.

The session was opened by Anthony E. Hanwell (King Edward VII School, Sheffield), who, under the title "The Value of the History of Science in a Sixth-form Science Course", gave an account of a course involving two periods a week for two years. The course began with the early attempts of man to exploit and adapt himself to his environment, all of which were characterized by the lack of a desire to seek theoretical explanations of the processes used. This was followed by attention to the study of Nature by the early Greek philosophers; to the Roman attitude to such matters; to the general decline in learning in the Dark Ages, and the impact upon European thought and life of the rise of Arabic nationalism and the recovery of the ancient Greek writings.

The course dealt fully with the lives of Copernicus, Tycho Brahe and Kepler, and the far-reaching effects of the work of Newton. Other sections were concerned with the histories of magnetism, electricity and light, to which a considerable amount of time was given; but it was surprising to learn that the history of biology was dealt with only in outline, and that of geology apparently not at all.

The speaker said that he was impressed by the way in which the study of the experiments of the pioneers emphasized the necessity for accurate observation. This in ordinary class-room work seemed directed mainly toward "obtaining a more accurate answer to a particular experiment, when if the answer were known it is usually possible to surreptitiously modify the observations". He appreciated the necessity for dealing with failures as well as with successes, and concluded that "a history of seience course can do much to rectify the errors of undue specialization" by providing the scientist with a broader knowledge of his subject, its aims, its limitations, and its possibilities for good.

In a paper entitled "British Finches", Kenneth R. Hughes, of Chesterfield, gave the results of observations on three of the common species that he had kept under observation. The behaviour of some kept under aviary conditions was found to be identical with that of the wild birds. From accounts of mating displays, nest-making and brood-rearing it appeared that the courting of bullfinches began in mid-April and lasted for about a fortnight. Nestbuilding began soon after mating and when incubátion cornmenced the cock was rarely seen near the nest, though he shared in the feeding of the young while the hen was sitting on her second clutch. When the birds of the second brood were able to feed them. selves the whole family gathered and remained together until spring, changing their summer woodland habitat for gardens and allotments during autumn and winter. In March the flocks separated into pairs and the yearly cycle began again.

Hawfinches next received attention. The courtship was seen to be a vigorous affair in which the female seems almost to be driven to build a nest. The young are reared on insects, and it is only later that they become the enemies of fruit growers and gardeners.

The work is continuing, for Kenneth Hughes has seven other species under observation. He regards finches as suitable for his purpose on account of the case with which they may be kept under conditions almost natural to them.

Miss Anne Bunting contributed a paper on "Some Little-known and Unpublished Aspects of the LifeHistory and Habits of Periplaneta americana (L.)". Having reared the large American cockroach for a number of years, she had come to the conclusion that the periods of incubation and of growth from incubation to final moult were shorter than is stated 
in text-books. She found that the incubation period lengthens as the temperature decreases, that below $50^{\circ} \mathrm{F}$. no incubation takes place, and that oothecæ submitted to this low temperature do not incubate if later exposed to more favourable temperatures. This was suggested as a partial explanation of the failure of the species to become widely established in Great Britain. Miss Bunting is a pupil of Thorne Grammar School, near Doncaster.

Keith I. Watson (Charterhouse) described "The Charterhouse Astronomical Project", the chief object of which was to revive within the school an astronomical society, first conceived when an observatory was added to the science laboratories in 1907. A retired master, Mr. R. C. Sclater, set up an observatory in his garden and made it a practice to invite parties of boys to make use of his telescope at week-ends. Unfortunately, he soon died and the project collapsed, to be revived again about four years later, in 1936. The organizers decreed that only sixth-form boys could become members---a rule that has now been wisely abandoned on the grounds that in order to maintain continuity with a changing schoolpopulation it is necessary to encourage the younger boys to take part. The work had to be suspended when war broke out and the observatory was used as a fire-watching post.

The present project was commenced in 1953 through the influence of a physics master, $\mathrm{Mr}$. Hayward, and has been encouraged and assisted by a local medical practitioner, Dr. Lyne-Pirkis. To use Keith Watson's own words, "on a clear evening we are at liberty to telephone him and he picks us up in his car and takes us to his observatory where we always spend a very pleasant and instructive evening".

The work planned for the society is determined by the equipment available. The mirror of its original 61 -in. reflecting telescope has been damaged, and since they cannot afford to pay for it to be repaired professionally the members intend to grind a new mirror for themselves. They now have also a 3 -in. Cooke refractor, which, being simpler to use, is more popular.

Some of the boys are mapping portions of the Moon's surface, paying special attention to regions on the edge of the disk that, being difficult to observe and in many cases not very interesting, tend to be neglected by most astronomers. The main task of the solar section has been to plot the course and cycles of sunspots.
The society has about fifty members, but as with most local societies only a few are really active, the others being what Keith Watson aptly described as satellites, attending lectures but doing little practical work. It is interesting to record that a paper embodying observations on "Bee-eaters in Britain" was read by another Charterhouse boy, James J. Swift, at another session of the Section.

The last paper was on "The Ecology of Porter Brook", by John K. Chesters (High Storrs Grammar School, Sheffield). It was a description of work done on the headstream of the River Porter, which runs off the moors on the west side of Sheffield.

Animals were collected in a Surber net, the horizontal frame of which marked out one square foot of the bottom surface. The net faced upstream and collected all the animals loosened from the rocks and the bottom debris. The contents of the net were washed into jars and afterwards sorted, counted and identified.

A chart was prepared expressing the results of the count in terms of the distance in feet from the source of the brook and the months in which the samples were taken. This revealed interesting variations in the number and relative importance of several stonefly nymphs and chironomid larvæe in various parts of the brook and at various times of the year, and showed that annelid worms were found in large numbers near the source of the stream but not elsewhere.

As one of several examples of the results obtained, it was pointed out that the numbers of chironomid larvæ increased greatly (in April and May) at the junction of the Porter Brook with another small stream, the Mayfield. Since the larvæ live in the bottom organic debris and are liable to be swept away by fast bottom currents it was thought that their greater abundance in the combined stream was due to there being a relatively slower bottom current in the somewhat deeper water. Tests showed that on similar bottoms the bottom velocity above the junction was twice as great as below it.

The general conclusions arrived at were that the main factors affecting life in the stream during winter and early spring were the velocity and volume of the water, but that during the remainder of the year there were complications due to other factors such as the amount of vegetation overgrowing the stream and controlling not only the supply of higher plant material but also the intensity of illumination.

F. J. NORTH

\section{OBITUARIES}

\section{Dr. G. J. H. Swoboda}

Gustave Swoboda, who died at Geneva on September 4, aged sixty-three, was widely known to meteorologists as the administrative head of the pre-war International Meteorological Organization and its successor, the World Meteorological Organization. Swoboda was a Czech (he later acquired Swiss nationality), a native of Prague, where he graduated in 1920 with the degree of Ph.D. In the same year he joined the State Meteorological Institute and ultimately became chief of the forecasting service. During this period he lectured on meteorology at the technical college in Prague and wrote a technical treatise on aeronautical meteorology. He was one of the first meteorologists outside Norway to give wholehearted support to the ideas of the Bjerknes school, and among other works he collaborated with ' '. Bergeron in a memorable essay on waves and vortices on a quasi-stationary surface.

The turning point in Swoboda's career came when he was appointed a member of the International Meteorological Organization's Commissions for Synoptic Weather Information and for Aeronautical Meteorology. The International Meteorological Organization was a non-governmental body, super- 